\title{
Influence of bio-fertilizer containing beneficial fungi and rhizospheric bacteria on health promoting compounds and antioxidant activity of Spinacia oleracea L.
}

\author{
Muhammad Khalid ${ }^{1 \dagger}$, Danial Hassani ${ }^{1 \dagger}$, Muhammad Bilal $^{2}$, Fayaz Asad ${ }^{3}$ and Danfeng Huang ${ }^{1 *}$
}

\begin{abstract}
Background: This study evaluates the influences of bio fertilizers containing mycorrhizal fungi (Glomus fasciculatum, Glomus mosseae) individually or in combination with N-fixer (Azotobacter chroococcum), K solubilizer (Bacillus mucilaginous) and P solubilizer (Bacillus megaterium) on soil fertility and phytochemical levels of spinach.

Results: Root colonization by mycorrhizal fungi was increased in the presence of bacterial inoculation in comparison to individual inoculation treatments. Inoculation of bio fertilizer containing mycorrhizal fungi and bacterial species considerably augmented the concentration of total phenolic compounds, flavonoids and phenolic acid contents. The 1, 1-diphenyl-2-picrylhydrazyl (DPPH) scavenging capacity of spinach was found to be positively coincided with flavonoid contents, while partially correlated with total phenolic compounds and phenolic acids. Further, the HPLC analysis showed that significantly higher antioxidant activity of spinach was correlated with quercetin contents and chlorogenic acid. Chlorophyll contents were also increased following the bio fertilization treatments.
\end{abstract}

Conclusion: Results revealed that these microbes are useful tool for improving health promoting compounds in spinach.

Keywords: Bio fertilizer, Arbuscular mycorrhizal fungi, Rhizospheric bacteria, Health-promoting compounds, Spinach

\section{Introduction}

The consumption of fruits and vegetables could increase the human innate immunity against chronic diseases (Bagchi et al. 2003; Yochum et al. 1999). The phytoconstituents including polyphenols, quercetin and flavonoids are largely demonstrated as important antioxidants and exhibit profound radical scavenging capabilities (Bravo 1998; Chu et al. 2000; Duthie et al. 2000; Gil et al. 1999; Middleton and Kandaswami 1994). Spinacia oleracea L. is one of the most important and commonly consumed leafy vegetable. It is commercially known as spinach

\footnotetext{
*Correspondence: hdf@sjtu.edu.cn

${ }^{\dagger}$ Muhammad Khalid and Danial Hassani contributed equally as the first author

${ }^{1}$ School of Agriculture and Biology, Shanghai Jiao Tong University, Shanghai 200240, People's Republic of China

Full list of author information is available at the end of the article
}

which is claimed to possess therapeutic properties and being a rich source of flavonoids as well as phenolic compounds besides its economical and ease of availability (Bunea et al. 2008; Ferreres et al. 1997; Metha and Belemkar 2014; Sultana and Anwar 2008). The pro-health properties of spinach are attributed to its low calorific value, and its large supply of vitamins, micro- and macronutrients and others phytochemicals, including polyphenols and fiber (Llorach et al. 2008). The quality of fresh vegetables could be assessed based on their nutritional value, growing conditions and usage of fertilizer. Despite the fact that the genetic modification and agronomic manipulation methods are widely used to improve the nutritional value of plants, the inadequate public acceptance and soil specificity of genetically modified food are still the challenges (Martínez-Ballesta et al. 2008). 
Started about 60 years ago, several studies have revealed the potentiality of beneficial microbes in increasing the plants resistance to biotic and abiotic stresses through the up-production of secondary metabolites (Shen 1997). Beneficial bacteria or fungi inhabit various sites such as plants rhizosphere, while others colonize on rhizoplane or even intercellular spaces (McCully 2001). Former studies revealed that phosphate and potassium solubilizing bacteria decompose the phosphate and potassium from their sources and make them available to the plants, assisting essential mineral uptake. Plant growth promoting rhizobacteria (PGPR) thrives in the rhizosphere of plants. It is worth mentioning that a substantial number of bacterial and fungal species entertain a functional relationship and establish an integrated system with the plants. They enhance the plant growth either by assisting in essential nutrients acquisition (minerals, nitrogen and phosphorus), eliciting pertinent hormones or acting as bio-control agents to reduce the inhibitory effects of various pathogens (Yang et al. 2009). Some strains such as Azotobacter chroococcum and Azospirillum brasilense have shown to possess properties of biological nitrogen fixation both in legume and non-legume, exerting a positive effect on overall physiology and development of the plants (Dobbelaere et al. 2001; Goldstein and Liu 1987). Former literature survey revealed 30\% improvement in the yield of wheat by the Azotobacter inoculation (Zablotowicz et al. 1991). Likewise, root/shoot length and dry weight has been significantly increased in tomato, lettuce and canola by inoculation of Pseudomonas putida and Pseudomonas fluorescens (Glick et al. 1997; Hall et al. 1996).

Arbuscular mycorrhizal fungi (AMF) are associated with majority of the plants, growing under natural conditions and its contribution for micronutrients uptake is well-documented in the previous reports. Moreover, these beneficial microbes protect the plants from oxidative stress by synthesizing antioxidant enzymes including, peroxidase, catalase, superoxide and non-enzymatic antioxidants such as glutathione, ascorbate and $\alpha$-tocopherol; hence, providing an suitable way to replace the hazardous agricultural chemical and agro-ecosystems destabilizing fertilizers.

The current study was appraised to evaluate the influence of beneficial bacteria (A. chroococcum, Bacillus megaterium and Bacillus mucilaginous) and fungi (Glomus fasciculatum and Glomus mosseae) on the antioxidant properties and physiological activities of S. oleracea L. and to develop an alternative method for improving the quality of health promoting phytochemicals and antiradical activity of spinach.

\section{Materials and methods}

\section{Chemicals and reagents}

Standard laboratory grade chemicals/reagents including, Folin-Ciocalteau reagent, 2,2-diphenyl-1-picrylhydrazyl radical (DPPH), gallic acid, ascorbic acid, Dithiothreitol (DTT), and ( \pm )-6-Hydroxy-2, 5, 7, 8-tetramethylchromane-2-carboxylic acid (Trolox) were mainly procured from Sigma-Aldrich (USA) and DSL Chemicals (Shanghai) Co., Ltd. All the experimental works were carried out in the Joint Laboratory of Digital Horticulture, School of Agriculture and Biology, Shanghai Jiao Tong University, Shanghai China.

\section{Soil}

Soil sample, was collected from the botanical garden of School of agriculture and biology, Shanghai Jiao Tong University, China. The collected soil was air-dried, grinded, passed through a sieve $(2 \mathrm{~mm}$ for chemical analysis and $8 \mathrm{~mm}$ for pot experiment) and mixed thoroughly. Soil was autoclaved three times and analyses were made prior to seeding. Basic properties of soil were; $\mathrm{pH}$, 7.32; EC, $0.14(\mathrm{dS} / \mathrm{m})$; available N, $111.6(\mathrm{ppm})$; available P, 181.7 (ppm), available K, 306.8 (ppm), cation exchange capacity (CEC), $13.2(\mathrm{cmol}(+) / \mathrm{kg}) ; \mathrm{NH}_{4}^{+}, 7.86(\mathrm{ppm})$; $\mathrm{NO}_{3}{ }^{-}, 2.67$ (ppm); total C, 1.92 (\%); total N, 0.19 (\%); total K, 2063 (ppm).

\section{Inocula development and bio-fertilizer}

Sterilized peat moss was chosen as a carrier for the rhizobacteria including $A$. chroococcum (nitrogen fixer), B. megaterium (phosphate solubilizer) and B. mucilaginous (potassium solubilizer) inoculums. All the bacterial strains were cultured in Luria-bertani (LB) broth at $28{ }^{\circ} \mathrm{C}$ for $48 \mathrm{~h}$ in a rotary shaker at an agitation speed of $120 \mathrm{rpm}$. After designated time period, the culture density was measured by means of a haemocytometer (improved neubauer counting chamber) following the previously described method (Wu et al. 2005). The strains were centrifuged at $5000 \mathrm{rpm}\left(\right.$ at $4{ }^{\circ} \mathrm{C}$ ) and resulting cells were thoroughly mixed with the sterilized peat moss. Mixture acting as the microbial inoculum contained a final population density of $1.33 \times 10^{8}, 2.08 \times 10^{8}$, $2.66 \times 10^{8} \mathrm{cfu} \mathrm{g}^{-1}$ inoculum (wet weight) for $\mathrm{K}, \mathrm{P}$ and $\mathrm{N}$ fixing bacteria, respectively. The sand-based two fungal inoculums consisting hyphae and spores were purchased from the Central bureau voor Schimmel cultures, Fungal Biodiversity Centre, Institute of the Royal Netherlands Academy of Arts and Sciences (KNAW).

\section{Experimental set up}

Greenhouse trial was conducted to investigate the efficiency of different combination of beneficial fungi and rhizobacteria on the growth and antioxidant profile of 
spinach. According to the treatment design, $15 \mathrm{~g}$ of sandbased mycorrhizal inoculum and $2 \mathrm{~g}$ of peat moss-based bacterial inoculum were inoculated into each pot according to treatment design. Treatments were set up for comparison, where 1st treatment (T1) considered as control with no fertilization, while the 2nd (T2) and 3rd (T3) treatment contained chemical fertilizers $\left(\mathrm{KCl}, \mathrm{KH}_{2} \mathrm{PO}_{4}\right.$ and urea) and autoclaved organic bio-fertilizer, respectively. The detailed information of experimental design has been listed in Table 1.

\section{Seeds germination and analysis}

The seeds of spinach were procured from Shanghai WELLS seed Co., LTD. Prior to sowing, the seeds were surface disinfected three times by soaking in $70 \%$ ethanol for $5 \mathrm{~min}$ and then in distilled water. After seed germination in each pot (height, $10 \mathrm{~cm}$; bottom diameter $9 \mathrm{~cm}$, top diameter $10 \mathrm{~cm}$, soil, $800 \mathrm{~g}$ per each pot), the seedling were thinned and only two seedling per pot were allowed to continue their growth. The pots were placed randomly in a greenhouse with an average temperature of $21 \pm 5.0^{\circ} \mathrm{C}$ and watered (twice a week) with distilled water to maintain the appropriate soil humidity level. After 45 days, the plants were harvested, collected and used for analytical purposes. Each treatment was carried out in 15 replicate pots to maintain the reproducibility of the data.

\section{Fungi and bacteria colonization assay}

At harvesting, the root were washed, treated with $\mathrm{KOH}$ (10.0\%) for $20 \mathrm{~min}$ at $90{ }^{\circ} \mathrm{C}$, acidified with HCL $1.0 \%$ for 3 min and then stained with trypan blue $0.05 \%$, and subjected to fungal root analysis in a manner as described previously (Giovannetti and Mosse 1980). Differentiating media with suspension dilution techniques from the soil samples were used to isolate and measure bacteria growth. For phosphate solubilizing bacteria:, $\mathrm{NaCl} 0.4 \mathrm{~g}$, $\left(\mathrm{NH}_{4}\right)_{2} \mathrm{SO}_{4} 0.6 \mathrm{~g}, \mathrm{Ca}_{3}\left(\mathrm{PO}_{4}\right)_{3} 9.0 \mathrm{~g}, \mathrm{KCl} 0.3 \mathrm{~g}, \mathrm{FeSO}_{4} \cdot 7 \mathrm{H}_{2} \mathrm{O}$ $0.03 \mathrm{~g}, \mathrm{MgSO}_{4} \cdot 7 \mathrm{H}_{2} \mathrm{O} 0.5 \mathrm{~g}, \mathrm{MnSO}^{4} \cdot 4 \mathrm{H}_{2} \mathrm{O} 0.03 \mathrm{~g}$, agar $21.0 \mathrm{~g}$, glucose $10.0 \mathrm{~g}$, sterilized water $1.0 \mathrm{~L}, \mathrm{pH}$ 7.0; for Nitrogen fixer:, $\mathrm{NaCl} 0.3$ g, 2\% congo red solution $6 \mathrm{~mL}$, $\mathrm{K}_{2} \mathrm{HPO}^{4} 0.4 \mathrm{~g}, \mathrm{MgSO}^{4} \cdot 7 \mathrm{H}_{2} \mathrm{O} 0.2 \mathrm{~g}, 3$ drops of $1 \% \mathrm{FeCl}_{3}$ and $1 \% \mathrm{MnCl}_{2}$ solution, agar $20.0 \mathrm{~g}$, glucose $10.0 \mathrm{~g}$, sterilized water 1.0 L, pH 7.0; for potassium solubilizing bacteria: $\mathrm{Na}_{2} \mathrm{HPO}_{4} 2.0 \mathrm{~g}, \mathrm{FeCl}_{3} 0.005 \mathrm{~g}, \mathrm{CaCO}_{3} 0.1 \mathrm{~g}, \mathrm{MgSO}_{4}$. $7 \mathrm{H}_{2} \mathrm{O} 0.5 \mathrm{~g}$, glass powder $1.0 \mathrm{~g}$, agar $20.0 \mathrm{~g}$, sucrose $5.0 \mathrm{~g}$, 1.0 L distilled water, pH 7.0 (Wu et al. 2005).

\section{Extract preparation of health-promoting compounds}

The phenolic compounds were extracted following the method previously described (Khalid et al. 2017). The phonolic compounds were extracted following the method previously described Frozen leaf tissue $(2.5 \mathrm{~g})$ was grinded with a mortar and pestle using $15 \mathrm{~mL}$ of $50 \%$ $(\mathrm{v} / \mathrm{v})$ acidified methanol $(0.1 \mathrm{M} \mathrm{HCl})$ and the phenolic compounds were extracted for $20 \mathrm{~min}$ at room temperature, then centrifuged at $9000 \mathrm{~g}$ for $30 \mathrm{~min}$. This procedure was repeated three times and the supernatants were combined to produce a crude extract of polyphenols. The raw methanolic extract was then evaporated to dryness under a vacuum at a temperature of $40{ }^{\circ} \mathrm{C}$ and rinsed with $100 \%$ methanol to a final volume of $10 \mathrm{~mL}$.

\section{Study of health promoting phytochemical HPLC-MS analysis}

Quantitative assessment of phenolic compounds was carried out through HPLC-MS (LTQ XL, Thermo Fisher Scientific, San Jose, CA, USA) analysis (Świeca et al. 2012). The HPLC-MS system was equipped with a ternary pump, auto sampler, and thermostatic column compartment, diode array detector (Surveyor, Thermo Fisher), and a linear ion trap mass spectrometer (LTQ XL, Thermo Fisher Scientific, San Jose, CA, USA) equipped with an electrospray ionization (ESI) source. A CORTECS C18 column $(2.1 \mathrm{~mm} \times 100 \mathrm{~mm}, 2.6 \mu \mathrm{m}$; Waters) was used; the column temperature was maintained at $35{ }^{\circ} \mathrm{C}$. The mobile phase A $(0.1 \%$ formic acid/ water) and $\mathrm{B}$ (acetonitrile) was used, the gradient program was as follows: $0-2 \min 5.0 \% \mathrm{~B} ; 4-11 \min 15-35 \%$ B; 15-17 min, $100 \% \mathrm{~B} ; 17.5-22 \mathrm{~min}, 5.0 \% \mathrm{~B}$; flow rate was $0.25 \mathrm{~mL} \mathrm{~min}^{-1}$, the injection volume was $4 \mu \mathrm{L}$. UV detection was performed at 270 and $370 \mathrm{~nm}$, the wavelength was scanned from 200-600 nm. MS was scanned in ESI source in negative mode, mass range: $m / z$ 92-1000;

\section{Table 1 Experimental design}

\begin{tabular}{|c|c|c|c|c|c|c|c|}
\hline Treatments & $\mathrm{T} 1$ & $\mathrm{~T} 2$ & T3 & T4 & T5 & T6 & T7 \\
\hline Bacteria inoculation & No & No & No & Yes & No & No & Yes \\
\hline Mycorrhizal fungi & None & None & None & None & Yes & Yes & Yes \\
\hline Fertilizer used & None & CF & $\mathrm{OF}^{\mathrm{A}}$ & None & None & None & None \\
\hline Code & Control & CF & OF & B & GF & GM & $\mathrm{B}+\mathrm{GF}+\mathrm{GM}$ \\
\hline
\end{tabular}

CF chemical fertilizer, OF ${ }^{A}$ organic fertilizer (autoclaved bio-fertilizer), B Azotobacter chroococcum + Bacillus megaterium + Bacillus mucilaginous, GF Glomus fasciculatum, GM Glomus mosseae 
source voltage was $3.5 \mathrm{kV}$, capillary temperature was $350{ }^{\circ} \mathrm{C}$, sheath gas flow was 35 , aux gas flow was 15.0 , sweep gas flow was 1.0, and capillary voltage was $43 \mathrm{~V}$. Data acquisition, handling, and instrument control were performed using Xcalibur 2.3.1 software.

\section{Determination of total phenolic contents, flavonoids and phenolic acid}

Total phenolic contents (TPCs) were determined by the method as reported earlier (Singleton et al. 1999). Briefly, $0.5 \mathrm{~mL} \mathrm{H}_{2} \mathrm{O}$ in combination with $2.0 \mathrm{~mL}$ Folin-Ciocalteau reagent $\left(1: 5 \mathrm{H}_{2} \mathrm{O}\right)$ was mixed with $0.5 \mathrm{~mL}$ of the plant sample. After 3-5 min of incubation at room temperature, $10 \mathrm{~mL}$ of $\mathrm{Na}_{2} \mathrm{CO}_{3}(10 \%, w / v)$ was added to the mixture and incubated at room temperature for $30 \mathrm{~min}$. Optical density of each sample was recorded at $725 \mathrm{~nm}$ in a UV-Vis spectrophotometer (HITACHI, U-2900) using Gallic acid as standard.

Total flavonoid contents (TFCs) were estimated in a manner described by (Lamaison and Carnat 1990). Shortly, $1.0 \mathrm{~mL}$ sample extract was allowed to react with $1.0 \mathrm{~mL}$ of aluminium chloride $\left(\mathrm{AlCl}_{3} \cdot 6 \mathrm{H}_{2} \mathrm{O}\right)$ solution $(2.0 \%, \mathrm{w} / \mathrm{v})$ for $10 \mathrm{~min}$ at room temperature and absorbance was monitored at $430 \mathrm{~nm}$.

A previously reported method of (Szaufer-Hajdrych 2004) was followed for measuring the phenolic acid contents (PACs) in the extracted sample. To this end, $1.0 \mathrm{~mL}$ of sample was thoroughly mixed with a combination of $5.0 \mathrm{~mL}$ of distilled water, $1.0 \mathrm{~mL} \mathrm{HCl}(0.5 \mathrm{M})$, Arnov reagent and $\mathrm{NaOH}(1 \mathrm{M})$ followed by OD measurement at $490 \mathrm{~nm}$.

\section{Chlorophyll measurement}

Chlorophyll content was evaluated as reported (Lin et al. 2013). Freeze-dried leaves samples were grinded with acetone, centrifuged at 13,000 rpm for $5.0 \mathrm{~min}$. Supernatants were collected and spectrophotometrically measured at 663 and $645 \mathrm{~nm}$ to analyze chlorophyll a, and chlorophyll b.

\section{Total antioxidant activity}

For antioxidant activity, free radical scavenging assay was carried out using 1, 1-diphenyl-2-picrylhydrazyl (DPPH) as described (Brand-Williams et al. 1995; Khanam et al. 2012). An $80 \mu \mathrm{L}$ of methanolic extract was mixed with $1.92 \mathrm{~mL}$ DPPH solution, and absorbance was immediately noted at $515 \mathrm{~nm}$. The quenching affinity of the sample was measured according to the relation given below.

$$
\text { Scavenging }(\%)=[(\mathrm{AC}-\mathrm{AA}) / \mathrm{AC})] \times 100
$$

where, AC represents the control absorbance at " 0 " $\min$ and AA denotes the absorbance of sample after " $t$ " time.

\section{Statistical analysis of data}

All the analytic determinations were carried out in triplicates. Statistical analysis was performed using STATISTICA 7.0 software for mean comparison using Tukey's test at the significance level of $P<0.05$.

\section{Results and discussion}

Colonization assay results in Fig. 1 manifest that the plant roots were found to be significantly colonized by Arbuscular mycorrhizal fungi (AMF) as compared to un-inoculated control treatments. Inoculation with beneficial bacteria and both G. fasciculatum and G. mosseae in $\mathrm{T} 7$ treatment led to augmented root as compared to $\mathrm{T} 5$ and T6. It has been demonstrated that the rhizobacteria can elicit the ability of mycorrhizal fungi in colonizing plant roots (Fitter and Garbaye 1994). Though, the exact mechanism underlying this triggering pathway is still unclear, but the up-production biosynthesis of plants hormones and vitamins as a result of bacterial infection may be involved in this process (Barea et al. 2002). The presence of beneficial rhizobacteria might cause the germination of a large number of spores by fungi, and as a consequence higher chances to infect/colonize plant roots (Tandon and Prakash 1998). It is not surprising that some beneficial bacteria actively secrete pectinolytic and cellulolytic enzymes that could further assist in mycorrhizal infection (Verma et al. 2001). In an earlier study, A. chroococcum has been isolated from the rhizospheric soil of Spinacia oleracea (Jiménez et al. 2011). Similarly, (Çakmakçı et al. 2007) reported that B. megaterium and $B$. mucilaginous successfully colonized rhizospheric zone in wheat and spinach. Recently (Song et al. 2015) observed a great synergy between the above mentioned strains and their aptitude to improve the quality of soil.

The present findings indicate that the level of bacteria (A. chroococcum, B. megaterium, B. mucilaginous) in the

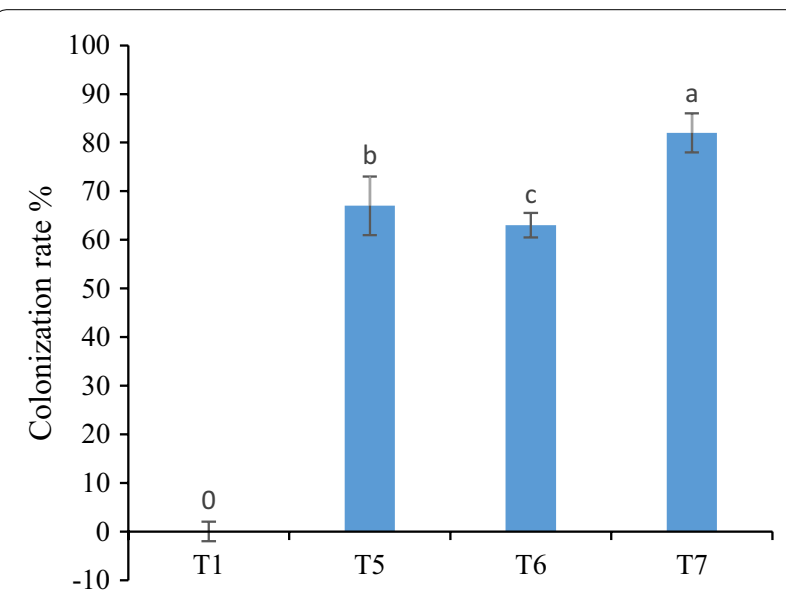

Fig. 1 Arbuscular mycorrhizal fungi infection rate of plant root after harvest in co-inoculated plants 
rhizosphere as well as AMF integration in the roots was different in co-inoculated treatments (Fig. 1; Table 2). The numbers of bacteria and AMF infection were found to be higher in T7 compared to T4, 5 and 6 treatments (Tables 1,2 ) suggesting the auxiliary property of microorganism in combination with each other.

\section{HPLC analysis results from spinach extract}

The possible compounds were identified by MS1, MS2 fragments and compared with the reported literatures (Kim et al. 2008; Ribas-Agustí et al. 2011; Złotek et al. 2014). The retention time, $\mathrm{m} / \mathrm{z}$ in negative mode, MS2 fragments and the possible chemical name are listed in Table 1. The major antioxidant and health benefiting compounds that were identified such as caffeic acid, ferulic acid, flavones (luteolin), flavonols (quercetin, kaempferol), isorhamnetin-3-gentiobioside-7-glucoside have been reported variously in previous studies in spinach (Alarcón-Flores et al. 2014; Justesen 2001; Nuutila et al. 2002). Chlorogenic acid, coumaric acid are also reported by Okazaki and coworkers while analyzing the effect of nitrogen concentration on the constituent's profile of spinach (Okazaki et al. 2008).

\section{Influence of experimental treatments on health promoting compound in spinach leaves}

In view of potential medicinal and preventive roles of secondary metabolites in chronic diseases such as cancer, cardiovascular and neurodegenerative disorders (Riedel et al. 2012), the health promoting metabolites of spinach were analyzed. Results showed that the total phenolic, flavonoids and phenolic acid contents were found to be significantly varied under different experimental treatments. The amount of total phenolic contents was 58.72 and $51.43 \%$ higher in $\mathrm{T} 5$ and $\mathrm{T} 7$ treatment, respectively, as compared to un-inoculated control plants (Fig. 2). Similar to our findings, the eliciting effect of $A$. chroococcum and G. fasciculatum on various other plants growth and total phenolic compounds have been observed (Baslam et al. 2011; Teixeira da Silva and Egamberdieva 2013). The flavonoid content was evaluated under different treatments and results are shown in Fig. 2. It was observed that experimental plants co-inoculated with $G$. fasciculatum and G. mosseae showed the highest content of flavonoids in T5 and T6, which were 48.02 and
$40.46 \%$ greater than that of control plants. Investigation of antioxidant biosynthesis and induction of phytochemicals including flavonoids by AMF has earlier been documented in several reports (Carlsen et al. 2008; Eftekhari et al. 2012; Nisha and RajeshKumar 2010). Similarly, phenolic acids were also recorded to be significantly higher in all treatments compared with control. Nevertheless, the T4 treatment and T7 treatment led to the 27.68 and $28.07 \%$ higher values, respectively in comparison to uninoculated plants. The results were in good agreement with (Taie et al. 2008) who have reported up to $75 \%$ improvement of phenolic acid biosynthesis in Rhizobacteria inoculated soybean seedling.

\section{Antioxidant activity}

The results of antioxidant activity analyzed through DPPH scavenging assay are portrayed in Fig. 2. It was observed that utmost antioxidant activity was determined in T7 (1.9 mM Trolox/g FW) elicited by bacterial and fungal combination followed by $\mathrm{T} 6(1.8 \mathrm{mM}$ Trolox/g FW) treated with fungus G. mosseae. Observed improvements in antioxidant level were 70.17, 66.66 and $61.29 \%$ for T7, T6 and T4, respectively, as compared to control (without any bacterial and fungal inoculation). The DPPH scavenging capacity of spinach was found to be positively coincided with flavonoid contents, while partially correlated with total phenolic compounds and phenolic acids. Polyphenols are important class of biologically-active compounds with extensively reported antioxidant characteristics. However, other properties, such as, the capability to suppress enzymes [lipoxygenase or cyclooxygenase (COX)] involved in the inflammation process have recently taken more attention (Gawlik-Dziki et al. 2011; Mulabagal et al. 2010). Nevertheless, earlier reports highlighted that antioxidant capacity of any plant extract highly depends on the type and relative proportion of phenolics presence. In our study, the significantly higher DPPH scavenging potential of spinach might be positively correlated with quercetin contents and chlorogenic acid (Table 4). The results strongly corroborates with (Kim et al. 2007; Liu et al. 2007) who observed pronounced antioxidant activity of lettuce in the presence of quercetin and chlorogenic acid, while luteolin and caffeic acid negatively influences the antioxidant activity. In addition to phenolic compounds, several other bioactive

Table 2 Population of beneficial bacteria in the rhizosphere of co-inoculated spinach after 45 days of growth

\begin{tabular}{|c|c|c|c|}
\hline Treatment & NFB $\left(10^{4} \mathrm{cfu} / \mathrm{g}\right.$ dry soil) & PSB (10 cfu/g dry soil) & KSB $\left(10^{6} \mathrm{cfu} / \mathrm{g}\right.$ dry soil $)$ \\
\hline T4 & $30.6 \pm 3.30 b$ & $44.1 \pm 0.09 b$ & $44.2 \pm 1.50 b$ \\
\hline $\mathrm{T7}$ & $63.1 \pm 11.5 \mathrm{a}$ & $79.8 \pm 3.55 a$ & $74.7 \pm 3.91 \mathrm{a}$ \\
\hline
\end{tabular}

NFB nitrogen fixing bacteria, $P S B$ phosphate solubilizing bacteria, $K S B$ potassium solubilizing bacteria 

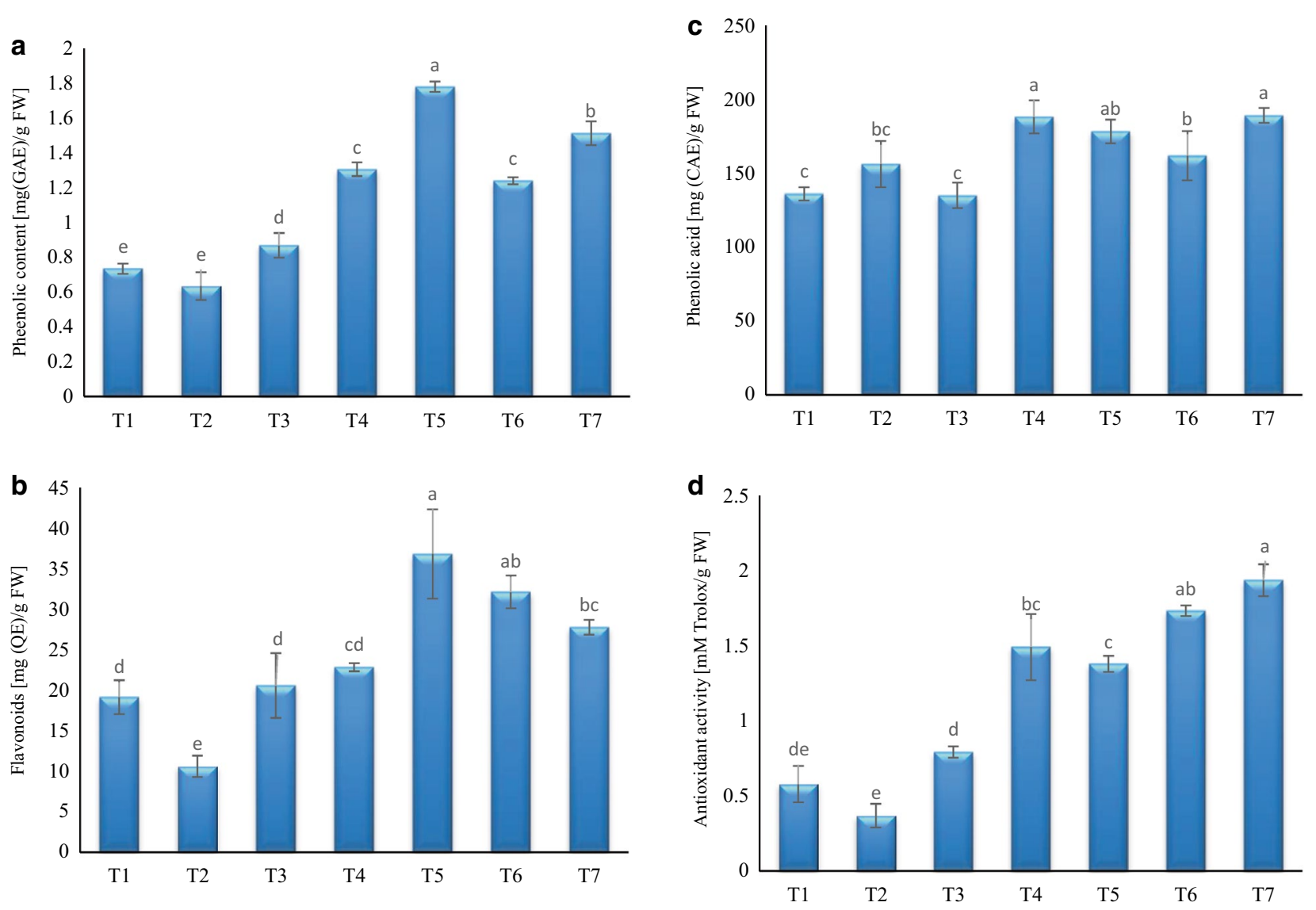

Fig. 2 Influence of selected treatments on a phenolic contents, b flavonoids, c phenolic acids, $\mathbf{d}$ antioxidant activity

constituents such as carotenoids and vitamins particularly vitamin $C$ potentially contribute a key role in the elicitation of antioxidant potentialities of the plants (Sun et al. 2012).

\section{Chlorophyll content}

Green leafy vegetables are known to be the richest source of major dietary metabolites. Spinach possess a considerable amount of chlorophyll which play critical role in reducing the risk of cancer and cardiovascular diseases (CVDs) (Caldwell and Britz 2006). It has been demonstrated that antioxidant rich diets, particularly chlorophyll inhibit the functions of COX-1 and COX-2 (Kim et al. 2007; Mulabagal et al. 2010). There are a variety of previously reported studies concerning the stimulating effect of rhizobacteria combination in co-cultivation with Ociumum basilicm L. (Vivas et al. 2003). The responses of chlorophyll contents in spinach treated with different elicitors are illustrated in Table 4. Chlorophyll a content was recorded to be significantly higher in plants co-inoculated by $A$. chroococcum, B. megaterium and B. mucilaginous bacterial strains (T4) in contrast with the control.
Whereas, no significant difference was observed in chlorophyll a content between the control and T3, T5 and T6 treatments (Table 4). The co-cultivation of plants with Mycorrhizal fungi as well as chemical and organic fertilizer had no important impact on chlorophyll b content whereas a significantly higher chl b content was recorded in experimental treatment inoculated with bacterial strains (T4) (Table 3). Bacterial inoculation had also an elevating role in total chlorophyll content $(a+b)$. Chemical fertilizer (T2) as well as bacterial and fungal strains combination treatment (T7) displayed higher values $458.66 \pm 7.27 \mathrm{~b}$ and $515.79 \pm 13.15 \mathrm{c}$, respectively. No significant difference was observed in other treatments (Table 4).

\section{Conclusions}

In the light of above findings, it is concluded that the application of bio fertilizer containing beneficial microbes displayed a stimulating effect on the soil properties and health qualities of spinach. The rhizobacterial inoculation resulted in increase of root infection by arbuscular mycorrhizal fungi. Moreover, the total 
Table 3 List of constituents based on the of HPLC analysis of Spinacia oleracea L extract

\begin{tabular}{|c|c|c|c|c|}
\hline$\overline{t_{R}}$ & Negative mode $(\mathrm{m} / \mathrm{z})$ & Possible compound & Chemical name & $\mathrm{MS}^{2}(-)$ \\
\hline 0.93 & 193 & $\mathrm{C}_{10} \mathrm{H}_{10} \mathrm{O}_{4}$ & Ferulic acid & 175 \\
\hline 0.98 & 179 & $\mathrm{C}_{9} \mathrm{H}_{8} \mathrm{O}_{4}$ & Caffeic acid & 161,143 \\
\hline 1.58 & 353 & $\mathrm{C}_{16} \mathrm{H}_{18} \mathrm{O}_{9}$ & Chlorogenic acid & 335,249 \\
\hline 1.67 & 285 & $\mathrm{C}_{15} \mathrm{H}_{10} \mathrm{O}_{6}$ & Kaempferol & 267,225 \\
\hline 4.26 & 285 & $\mathrm{C}_{15} \mathrm{H}_{10} \mathrm{O}_{6}$ & Luteolin & $267,225,153$ \\
\hline 6.85 & 295 & $\mathrm{C}_{13} \mathrm{H}_{12} \mathrm{O}_{8}$ & Caffeoylmalic acid & 163,149 \\
\hline 7.10 & 163 & $\mathrm{C}_{9} \mathrm{H}_{8} \mathrm{O}_{3}$ & Coumaric acid & 119 \\
\hline 7.60 & 787 & $\mathrm{C}_{33} \mathrm{H}_{40} \mathrm{O}_{22}$ & Quercetin-3-gentiobioside-7-glucoside & $772,769,655,637,505,373,330,313$ \\
\hline 8.20 & 801 & $\mathrm{C}_{34} \mathrm{H}_{42} \mathrm{O}_{22}$ & Isorhamnetin-3-Gentiobioside-7-glucoside & $786,769,669,651,387,345,330,329$ \\
\hline 8.51 & 465 & $\mathrm{C}_{20} \mathrm{H}_{22} \mathrm{O}_{9}$ & Cassiaside & $437,407,379,259,241$ \\
\hline 8.63 & 301 & $\mathrm{C}_{15} \mathrm{H}_{10} \mathrm{O}_{7}$ & Quercetin & $283,265255,237$ \\
\hline 8.96 & 337 & $\mathrm{C}_{16} \mathrm{H}_{18} \mathrm{O}_{8}$ & 5-p-coumaroylquinic acid & 277,191 \\
\hline 10.3 & 521 & $\mathrm{C}_{30} \mathrm{H}_{34} \mathrm{O}_{8}$ & Benzoylgomisin $\mathrm{H}$ & 345 \\
\hline 12.1 & 519 & $\mathrm{C}_{29} \mathrm{H}_{28} \mathrm{O}_{9}$ & Schisantherin D & 343 \\
\hline 12.5 & 503 & $\mathrm{C}_{29} \mathrm{H}_{28} \mathrm{O}_{8}$ & Interiotherin A & 327 \\
\hline 12.8 & 533 & $\mathrm{C}_{27} \mathrm{H}_{34} \mathrm{O}_{11}$ & Phillyrin & 357 \\
\hline 16.5 & 311 & $\mathrm{C}_{13} \mathrm{H}_{12} \mathrm{O}_{9}$ & Caffeoyltartaric acid & 149 \\
\hline
\end{tabular}

Table 4 Influence of selected treatments on chlorophyll content in Spinach leaves

\begin{tabular}{llll}
\hline Treatment & \multicolumn{3}{l}{ Constituents $\mathbf{( m g / 1 0 0 ~} \mathbf{g ~ d w})$} \\
\cline { 2 - 4 } & Chl $\mathbf{a}$ & Chl b & Chl $\mathbf{~}+\mathbf{b}$ \\
\hline T1 & $237.45 \pm 3.7 \mathrm{~d}$ & $128.31 \pm 14.16 \mathrm{~g}$ & $365.33 \pm 8.67 \mathrm{f}$ \\
T2 & $335.23 \pm 6.45 \mathrm{~b}$ & $123.20 \pm 8.60 \mathrm{f}$ & $458.66 \pm 7.27 \mathrm{~b}$ \\
T3 & $206.33 \pm 7.61 \mathrm{e}$ & $140.74 \pm 2.42 \mathrm{~d}$ & $346.33 \pm 6.15 \mathrm{~g}$ \\
T4 & $474.24 \pm 10.41 \mathrm{a}$ & $312.62 \pm 17.04 \mathrm{a}$ & $786.83 \pm 20.79 \mathrm{a}$ \\
T5 & $251.91 \pm 18.22 \mathrm{C}$ & $149.80 \pm 11.03 \mathrm{C}$ & $400.25 \pm 10.83 \mathrm{~d}$ \\
T6 & $253.69 \pm 3.05 \mathrm{C}$ & $100.80 \pm 5.51 \mathrm{~g}$ & $354.10 \pm 22.17 \mathrm{f}$ \\
T7 & $351.28 \pm 13.40 \mathrm{C}$ & $163.45 \pm 18.07 \mathrm{~b}$ & $515.79 \pm 13.15 \mathrm{c}$ \\
\hline
\end{tabular}

Chl $a$ chlorophyll A, Chl $b$ chlorophyll B, Chl $a+b$ chlorophyll A and B

phenolic compounds, antioxidant activity and chlorophyll content were also significantly enhanced by bio fertilizer treatments. These outcomes suggested that exploration of microbes display a high potential for use in the improvement of nutritious properties of fresh vegetables which could be a potential alternative to conventional approaches. However the mechanism underlying this phenomenon is not yet fully understood and will be remained for further investigations.

\section{Authors' contribution}

MK and DH carried out the experiment work. MB and FA helped in drafting the paper and interpreting the data. All authors read and approved the final manuscript.

\section{Author details}

'School of Agriculture and Biology, Shanghai Jiao Tong University, Shanghai 200240, People's Republic of China. ${ }^{2}$ State Key Laboratory of Microbial
Metabolism, School of Life Sciences and Biotechnology, Shanghai Jiao Tong University, Shanghai 200240, China. ${ }^{3}$ Key Laboratory of Alpine Ecology and Biodiversity, Key Laboratory of Tibetan Environment, Changes and Land Surface Processes, Institute of Tibetan Plateau Research, Chinese Academy of Sciences, Beijing 100101, China.

\section{Acknowledgements}

This work was sponsored in part by the National High-tech R\&D Program of China (863 Program) (Grant No. 2013AA103000) and Shanghai Agriculture Applied Technology Development Program, China (Grant No. T20140502).

Competing interests

The authors declare that they have no competing interests.

Availability of data and materials

Not applicable.

\section{Consent for publication}

Not applicable.

Ethics approval and consent to participate

Not applicable.

\section{Publisher's Note}

Springer Nature remains neutral with regard to jurisdictional claims in published maps and institutional affiliations.

Received: 10 March 2017 Accepted: 11 August 2017

Published online: 16 August 2017

\section{References}

Alarcón-Flores MI, Romero-González R, Vidal JLM, Frenich AG (2014) Determination of phenolic compounds in artichoke, garlic and spinach by Ultra-High-Performance Liquid Chromatography coupled to Tandem Mass Spectrometry. Food Anal Methods 7:2095-2106

Bagchi D, Sen CK, Ray SD, Das DK, Bagchi M, Preuss HG, Vinson JA (2003) Molecular mechanisms of cardioprotection by a novel grape seed 
proanthocyanidin extract. Mutation Res Fundam Mol Mech Mutagen 523:87-97

Barea J, Azcón-aguilar C, Azcón R (2002) Interactions between mycorrhizal fungi and rhizosphere micro-organisms within the context of sustainable soil-plant systems. In: Gange AC, Brown VK (eds) Multitrophic interactions in terrestrial systems. pp 65-68

Baslam M, Garmendia I, Goicoechea N (2011) Arbuscular mycorrhizal fungi (AMF) improved growth and nutritional quality of greenhouse-grown lettuce. J Agric Food Chem 59:5504-5515

Brand-Williams W, Cuvelier M-E, Berset C (1995) Use of a free radical method to evaluate antioxidant activity. LWT-Food Sci Technol 28:25-30

Bravo L (1998) Polyphenols: chemistry, dietary sources, metabolism, and nutritional significance. Nutr Rev 56:317-333

Bunea A, Andjelkovic M, Socaciu C, Bobis O, Neacsu M, Verhé R, Van Camp J (2008) Total and individual carotenoids and phenolic acids content in fresh, refrigerated and processed spinach (Spinacia oleracea L.). Food Chem 108:649-656

Çakmakçı R, Erat M, Erdoğan Ü, Dönmez MF (2007) The influence of plant growth-promoting rhizobacteria on growth and enzyme activities in wheat and spinach plants. J Plant Nutr Soil Sci 170:288-295

Caldwell CR, Britz SJ (2006) Effect of supplemental ultraviolet radiation on the carotenoid and chlorophyll composition of green house-grown leaf lettuce (Lactuca sativa L.) Cultivars. J Food Compos Anal 19:637-644

Carlsen S, Understrup A, Fomsgaard I, Mortensen A, Ravnskov S (2008) Flavonoids in roots of white clover: interaction of arbuscular mycorrhizal fungi and a pathogenic fungus. Plant Soil 302:33-43

Chu YH, Chang CL, Hsu HF (2000) Flavonoid content of several vegetables and their antioxidant activity. J Sci Food Agric 80:561-566

Dobbelaere S, Croonenborghs A, Thys A, Ptacek D, Vanderleyden J, Dutto P, Labandera-Gonzalez C, Caballero-Mellado J, Aguirre JF, Kapulnik Y (2001) Responses of agronomically important crops to inoculation with Azospirillum. Funct Plant Biol 28:871-879

Duthie GG, Duthie SJ, Kyle JA (2000) Plant polyphenols in cancer and heart disease: implications as nutritional antioxidants. Nutr Res Rev 13:79-106

Eftekhari M, Alizadeh M, Ebrahimi P (2012) Evaluation of the total phenolics and quercetin content of foliage in mycorrhizal grape (Vitis vinifera L.) varieties and effect of postharvest drying on quercetin yield. Ind Crops Prod 38:160-165

Ferreres F, Castañer M, Tomás-Barberán FA (1997) Acylated flavonol glycosides from spinach leaves (Spinacia oleracea). Phytochemistry 45:1701-1705

Fitter A, Garbaye J (1994) Interactions between mycorrhizal fungi and other soil organisms. Plant Soil 159:123-132

Gawlik-Dziki U, Swieca M, Sugier D, Cichocka J (2011) Comparison of in vitro lipoxygenase, xanthine oxidase inhibitory and antioxidant activity of Arnica montana and Arnica chamissonis tinctures. Acta Sci Pol Hortorum Cultus 10:15-27

Gil MI, Ferreres F, Tomás-Barberán FA (1999) Effect of postharvest storage and processing on the antioxidant constituents (flavonoids and vitamin C) of fresh-cut spinach. J Agric Food Chem 47:2213-2217

Giovannetti M, Mosse B (1980) An evaluation of techniques for measuring vesicular arbuscular mycorrhizal infection in roots. New Phytol 84:489-500

Glick BR, Liu C, Ghosh S, Dumbroff EB (1997) Early development of canola seedlings in the presence of the plant growth-promoting rhizobacterium Pseudomonas putida GR12-2. Soil Biol Biochem 29:1233-1239

Goldstein A, Liu S (1987) Molecular cloning and regulation of a mineral phosphate solubilizing gene from Erwinia herbicola. Nat Biotechnol 5:72-74

Hall JA, Peirson D, Ghosh S, Glick BR (1996) Root elongation in various agronomic crops by the plant growth promoting rhizobacterium Pseudomonas putida GR12-2. Isr J Plant Sci 44:37-42

Jiménez DJ, Montaña JS, Martínez MM (2011) Characterization of free nitrogen fixing bacteria of the genus Azotobacter in organic vegetable-grown Colombian soils. Braz J Microbiol 42:846-858

Justesen U (2001) Collision-induced fragmentation of deprotonated methoxylated flavonoids, obtained by electrospray ionization mass spectrometry. J Mass Spectrom 36:169-178

Khalid M, Hassani D, Bilal M, Liao J, Huang D (2017) Elevation of secondary metabolites synthesis in Brassica campestris ssp. chinensis L. via exogenous inoculation of Piriformospora indica with appropriate fertilizer. PLoS ONE 12:e0177185
Khanam UKS, Oba S, Yanase E, Murakami Y (2012) Phenolic acids, flavonoids and total antioxidant capacity of selected leafy vegetables. J Funct Foods 4:979-987

Kim H-J, Fonseca JM, Choi J-H, Kubota C (2007) Effect of methyl jasmonate on phenolic compounds and carotenoids of romaine lettuce (Lactuca sativa L.). J Agric Food Chem 55:10366-10372

Kim KH, Lee KH, Choi SU, Kim YH, Lee KR (2008) Terpene and phenolic constituents of Lactuca indica L. Arch Pharmacal Res 31:983-988

Lamaison J, Carnat A (1990) Levels of principal flavonoids in flowers and leaves of Crataegus-Monogyna Jacq and Crataegus-Laevigata (Poiret) Dc (Rosaceae). Pharm Acta Helv 65:315-320

Lin K-H, Huang M-Y, Huang W-D, Hsu M-H, Yang Z-W, Yang C-M (2013) The effects of red, blue, and white light-emitting diodes on the growth, development, and edible quality of hydroponically grown lettuce (Lactuca sativa L. var. capitata). Sci Hortic 150:86-91

Liu X, Ardo S, Bunning M, Parry J, Zhou K, Stushnoff C, Stoniker F, Yu L, Kendall P (2007) Total phenolic content and DPPH radical scavenging activity of lettuce (Lactuca sativa L.) grown in Colorado. LWT-Food Sci Technol 40:552-557

Llorach R, Martínez-Sánchez A, Tomás-Barberán FA, Gil MI, Ferreres F (2008) Characterisation of polyphenols and antioxidant properties of five lettuce varieties and escarole. Food Chem 108:1028-1038

Martínez-Ballesta MC, López-Pérez L, Hernández M, López-Berenguer C, Fernández-García N, Carvajal M (2008) Agricultural practices for enhanced human health. Phytochem Rev 7:251-260

McCully ME (2001) Niches for bacterial endophytes in crop plants: a plant biologist's view. Funct Plant Biol 28:983-990

Metha D, Belemkar S (2014) PHARMACOLOGICAL ACTIVITY OF SPINACIA OLERACEA LINN.-A COMPLETE OVERVIEW. Asian J Pharm Res Dev 2:83-93

Middleton E Jr, Kandaswami C (1994) The impact of plant flavonoids on mammalian biology: implications for immunity, inflammation and cancer. The flavonoids. Chapman and Hall, London

Mulabagal V, Ngouajio M, Nair A, Zhang Y, Gottumukkala AL, Nair MG (2010) In vitro evaluation of red and green lettuce (Lactuca sativa) for functional food properties. Food Chem 118:300-306

Nisha MC, RajeshKumar S (2010) Influence of arbuscular mycorrhizal fungi on biochemical changes in Wedilla chinensis (Osbeck) Merril. Anc Sci Life 29:26

Nuutila A, Kammiovirta K, Oksman-Caldentey K-M (2002) Comparison of methods for the hydrolysis of flavonoids and phenolic acids from onion and spinach for HPLC analysis. Food Chem 76:519-525

Okazaki K, Oka N, Shinano T, Osaki M, Takebe M (2008) Differences in the metabolite profiles of spinach (Spinacia oleracea L.) leaf in different concentrations of nitrate in the culture solution. Plant Cell Physiol 49:170-177

Ribas-Agustí A, Gratacós-Cubarsí M, Sárraga C, García-Regueiro JA, Castellari M (2011) Analysis of eleven phenolic compounds including novel p-coumaroyl derivatives in lettuce (Lactuca sativa L.) by Ultra-high-performance Liquid Chromatography with photodiode array and mass spectrometry detection. Phytochem Anal 22:555-563

Riedel H, Akumo DN, Saw NMMT, Kütük O, Neubauer P, Smetanska I (2012) Elicitation and precursor feeding influence phenolic acids composition in Vitis vinifera suspension culture. Afr J Biotechnol 11:3000-3008

Shen D (1997) Microbial diversity and application of microbial products for agricultural purposes in China. Agric Ecosyst Environ 62:237-245

Singleton VL, Orthofer R, Lamuela-Raventos RM (1999) [14] Analysis of total phenols and other oxidation substrates and antioxidants by means of folin-ciocalteu reagent. Methods Enzymol 299:152-178

Song X, Liu M, Wu D, Griffiths BS, Jiao J, Li H, Hu F (2015) Interaction matters: synergy between vermicompost and PGPR agents improves soil quality, crop quality and crop yield in the field. Appl Soil Ecol 89:25-34

Sultana B, Anwar F (2008) Flavonols (kaempeferol, quercetin, myricetin) contents of selected fruits, vegetables and medicinal plants. Food Chem 108:879-884

Sun B, Yan H, Zhang F, Wang Q (2012) Effects of plant hormones on main health-promoting compounds and antioxidant capacity of Chinese kale. Food Res Int 48:359-366

Świeca M, Gawlik-Dziki U, Kowalczyk D, Złotek U (2012) Impact of germination time and type of illumination on the antioxidant compounds and antioxidant capacity of Lens culinaris sprouts. Sci Hortic 140:87-95

Szaufer-Hajdrych M (2004) Phenolic acids in leaves of species of the Aquilegia L. genus. Herba Pol 50:50-54 
Taie HA, El-Mergawi R, Radwan S (2008) Isoflavonoids, flavonoids, phenolic acids profiles and antioxidant activity of soybean seeds as affected by organic and bioorganic fertilization. Am Eurasian J Agric Environ Sci 4:207-213

Tandon V, Prakash A (1998) Influence of soil inoculation with VA mycorrhiza and phosphorus solubilising microorganisms on growth and phosphorus uptake in Sesamum indicum. Int J Trop Agric 16:201-209

Teixeira da Silva J, Egamberdieva D (2013) Plant-growth promoting rhizobacteria and medicinal plants. Recent Prog Med Plants 38:26-42

Verma SC, Ladha JK, Tripathi AK (2001) Evaluation of plant growth promoting and colonization ability of endophytic diazotrophs from deep water rice. J Biotechnol 91:127-141

Vivas A, Marulanda A, Ruiz-Lozano JM, Barea JM, Azcón R (2003) Influence of a Bacillus sp. on physiological activities of two arbuscular mycorrhizal fungi and on plant responses to PEG-induced drought stress. Mycorrhiza 13:249-256
Wu S, Cao Z, Li Z, Cheung K, Wong M (2005) Effects of biofertilizer containing $\mathrm{N}$-fixer, $\mathrm{P}$ and $\mathrm{K}$ solubilizers and $\mathrm{AM}$ fungi on maize growth: a greenhouse trial. Geoderma 125:155-166

Yang J, Kloepper JW, Ryu C-M (2009) Rhizosphere bacteria help plants tolerate abiotic stress. Trends Plant Sci 14:1-4

Yochum L, Kushi LH, Meyer K, Folsom AR (1999) Dietary flavonoid intake and risk of cardiovascular disease in postmenopausal women. Am J Epidemio 149:943-949

Zablotowicz RM, Tipping EM, Lifshitz R, Kloepper JW (1991) Plant growth promotion mediated by bacterial rhizosphere colonizers. In: The rhizosphere and plant growth. Springer, pp 315-326

Złotek U, Świeca M, Jakubczyk A (2014) Effect of abiotic elicitation on main health-promoting compounds, antioxidant activity and commercial quality of butter lettuce (Lactuca sativa L.). Food Chem 148:253-260

\section{Submit your manuscript to a SpringerOpen ${ }^{\circ}$ journal and benefit from:}

- Convenient online submission

- Rigorous peer review

- Open access: articles freely available online

- High visibility within the field

Retaining the copyright to your article

Submit your next manuscript at $\boldsymbol{\nabla}$ springeropen.com 